\title{
Prólogo terminável e interminável (sobre as primeiras peças de Peter Handke)
}

\author{
[Prologue terminable and interminable (on Peter Handke's early plays)] \\ http://dx.doi.org/10.11606/1982-88372443111
}

\begin{abstract}
Artur Sartori Kon ${ }^{1}$
Abstract: Addressing the set of so-called "spoken plays" or "speech plays" (Sprechstücke), the first four works written for the theater in the 1960s by Peter Handke, 2019 Nobel Prize for Literature, the essay seeks to locate in them more than the alienated self-referential game condemned by many in a supposed postmodernism. Relating the author's project with a properly Austrian modernist tradition and with the concerns of a possible political philosophy of language, we investigate his playwriting as a critical operation in relation to the coercive function of language, in order to finally relate this interest to its position in theater history, proposing its key role in understanding the contemporary scene.

Keywords: Peter Handke; contemporary theatre; Austrian literature; German theatre.

Resumo: Abordando o conjunto das chamadas "peças de fala" (Sprechstücke), as primeiras quatro obras escritas para o teatro ainda nos anos 60 por Peter Handke, Prêmio Nobel de Literatura de 2019, o ensaio busca localizar nelas mais do que o jogo autorreferencial alienado censurado por muitos num suposto pós-modernismo. Relacionando o projeto do autor com uma tradição modernista propriamente austríaca e com as preocupações de uma possível filosofia política da linguagem, investigamos essa dramaturgia como uma operação crítica em relação a um funcionamento coercitivo da linguagem, para ao fim relacionar esse interesse com sua posição na história do teatro, propondo seu papel chave para compreender a cena contemporânea.
\end{abstract}

Palavras-chave: Peter Handke; teatro contemporâneo; literatura austríaca; teatro alemão.

eu ainda falo versos e não fatos

MAIAKOVSKI (por Augusto de Campos)

\footnotetext{
${ }^{1}$ Universidade de São Paulo, Departamento de Filosofia, Av. Prof. Luciano Gualberto, 315, Cidade Universitária, São Paulo, SP, 05508-900, Brasil. E-mail: arturskon@ gmail.com. ORCID: 0000-0003-12824800

Pesquisador contratado através do processo no 2017/04905-9, Fundação de Amparo à Pesquisa do Estado de São Paulo (FAPESP).
}

\section{BY-NC}

Pandaemonium, São Paulo, v. 24, n. 43, mai.-ąo. 2021, p. 111-138 


\section{Despedaçando falas}

Insatisfeito com o teatro de seu tempo, o qual já incluía poéticas sofisticadas como a brechtiana e a beckettiana, bem como diversas formas de emulação e variação de ambas, ainda no início de sua carreira literária Peter Handke se propôs a redação de um manifesto que expusesse suas visões e, quem sabe, ajudasse a pôr uma pá de cal sobre essa arte moribunda. Que no processo de escrita esse libelo se transformasse ele mesmo em uma peça de teatro, eis o que o próprio autor a princípio não podia imaginar, de acordo com suas próprias declarações:

Eu por exemplo jamais tinha pensado que jamais escreveria peças. O teatro, como ele era, para mim era uma relíquia de um tempo passado. [...] As histórias no palco não tinham nada a ver comigo, elas eram, ao invés de simples, sempre apenas simplificações. As possibilidades da realidade eram limitadas pelas impossibilidades do palco [...]. O espaço fatal de significado (o palco significa o mundo) permanecia irrefletido e levava, para mim, a simbolismos inequívocos ridículos [...]. Simulava-se realidade onde havia ficção (HANDKE 2018: 33).

A curiosa inversão do projeto, fazendo surgir uma peça de teatro ali onde se queria produzir um ensaio contra o teatro, faz-se sentir não apenas nesse primeiro resultado, mas pelo menos em todo o conjunto das quatro primeiras peças de Handke, para as quais ele inventou o termo Sprechstücke: "peças faladas", como têm sido traduzidas ${ }^{2}$, mas mais ainda "peças de fala": não apenas obras de teatro, mas pedaços de linguagem, nacos de discurso tomados da realidade e enxertados na cena, um pouco como ready-mades literários com forte carga de oralidade (abrindo caminho para uma rica transposição cênica). Continuando a reflexão citada acima, o autor explica o método de suas primeiras peças como "uma limitação das ações teatrais a palavras, cujos significados contraditórios impedem uma ação e uma história individual"; esse método significava que "todos os métodos até então eram negados", de modo "que não fosse dada mais nenhuma imagem da realidade, que a realidade não fosse representada e apresentada", mas antes "se jogava com palavras e frases da realidade" (ibid.; lembremos que, em alemão, já essa declaração de Handke é um jogo com a linguagem, pois é o verbo spielen que se desdobra em representar, apresentar e jogar, de modo semelhante ao inglês play).

\footnotetext{
${ }^{2}$ Essas peças foram publicadas no Brasil apenas em 2015, em volume bilíngue. Adiante discutirei alguns dos graves problemas dessa tradução de Samir Signeu, os quais infelizmente prejudicam (sem inutilizar por completo, é claro) o importante trabalho de tornar essas obras disponíveis para o público brasileiro. Mas cabe considerar também que em diversas dessas escolhas tradutórias que considero questionáveis Signeu segue as soluções mais comuns em outras línguas, sobretudo o francês (cuja tradição de traduzir "literalmente" os textos literários é particularmente traiçoeira no caso de Handke, totalmente baseada nos jogos de linguagem).
}

Pandaemonium, São Paulo, v. 24, n. 43, mai.-ago. 2021, p. 111-138 
KON, A. S. - Prólogo terminável e interminável

Justamente devido a esse aspecto, antes de apresentar brevemente cada uma das peças, cabe uma consideração sobre seus nomes: a tradução no Brasil como Insulto ao público, Autoacusação, Predição e Gritos de socorro perde algo essencial do texto de partida: o modo como os quatro títulos operam com o mesmo modo de compor substantivos a partir de palavras menores (as Komposita próprias do idioma alemão) e quase sempre com o mesmo sufixo (que indica a substantivação de verbos), explicitando assim que servem menos para nomear uma ideia ou um tema do que como descrição objetiva do material e tratamento que serão encontrados no texto (um pouco como quem dá a um quadro o título "Composição em azul" ao invés de "Céu e mar"). Assim, proporíamos verter Publikumsbeschimpfung, Selbstbezichtigung, Weissagung e Hilferufe antes como Afrontando o público, Acusando a si mesmo, Predizendo o futuro e Chamando por socorro ${ }^{3}$. Espero poder mostrar que, longe de qualquer preciosismo, essa mudança na tradução nos ajuda a ler nas peças aquilo que elas têm de mais significativo.

Afrontando o público estreou em 1966, no Theater Am Turm de Frankfurt, com direção de Claus Peymann. Os 67 parágrafos que constituem a peça são atribuídos simplesmente a "quatro oradores" (PF: 87), sem divisões entre eles, sem rubricas indicando ações ou cenário. ${ }^{4}$ Há, antecedendo-os na versão publicada, uma série de "instruções para os atores", sugerindo como modelos para a enunciação desde "as ladainhas nas igrejas católicas" ou "o coro da multidão nas manifestações" até "a partida e a parada do motor de uma betoneira" e "o hit-parade da rádio Luxemburgo" (88). Há ainda uma série de sugestões para a entrada do público na sala, buscando gerar certa expectativa: os espectadores devem encontrar "o ambiente habitual que precede ao início de um espetáculo", mas também se ouve "nos bastidores [...] uma agitação ou um tráfego ruidoso", é entregue um programa com "uma elegância especial", e até "os gestos das funcionárias do teatro que fecharão as portas serão marcados por uma gravidade toda especial" (89).

Quando a cortina se abre, porém, o palco está vazio. Para o resto da peça, as indicações procuram construir uma suposta neutralidade, mais negando hábitos teatrais

\footnotetext{
${ }^{3}$ Essa última poderia ser também “Chamado de socorro", já que no alemão é o único título sem a terminação em -ung, mas prefiro manter a unidade das quatro peças. Já no caso da primeira peça, a escolha do verbo "afrontar" ao invés de "insultar", ou mesmo "xingar", apesar de fazer o título soar mais ameno e menos provocativo, permite manter o eco entre Beschimpfung e Bezichtigung ("afrontando" e "acusando").

${ }^{4}$ As quatro peças de fala serão citadas a partir da edição brasileira, na tradução de Samir Signeu, que eu indico pela sigla PF, e corrijo ou modifico quando necessário (ver nota 1 acima).
}

Pandaemonium, São Paulo, v. 24, n. 43, mai.-ago. 2021, p. 111-138 
KON, A. S. - Prólogo terminável e interminável

do que propondo de fato uma encenação: a iluminação é a "normal de um fim de espetáculo", "a mesma" no palco e na sala, e "permanecerá idêntica durante toda a peça"; os atores, ou melhor, oradores, "vestem roupas quaisquer" e "a maneira de eles andarem não tem nada de especial"; quando falam, "não é preciso colocar intenções nas palavras" e nem "atribuir significados à maneira de falar"; finalmente, não há personagens ou diferenças entre eles: "eles têm que preencher um papel quase que igual" (90-1). Ora, também aquilo que eles falam reforça essa recusa da teatralidade tal como entendida até então, incluindo desde versões mais tradicionais do drama até modalidades então em voga (como o teatro documentário):

Nossas palavras não mais se dirigem aos seus olhares. Suas olhadelas não mais remendam nosso diálogo. [...] Nós não mostramos nada para vocês. Nós não estamos representando destinos. Nós não estamos representando sonhos. Isto não é uma reportagem. Isto não é um documentário. Isto não é uma fatia da vida. Nós não vamos contar para vocês uma história. Nós não representamos quaisquer ações. Nós não simulamos quaisquer ações. Nós não representamos nada. Nós não impomos nada a vocês. Nós apenas falamos (93$4)$.

É dessa longa arenga que a peça é feita em sua maior parte, negando todas as possibilidades habituais do teatro: aqui não há "objetos que aparentam ser outros objetos" ou "um tempo que aparenta ser outro tempo" (95), mas o tempo e o espaço do palco, o mesmo vivido pela plateia. Ao menos é o que diz o texto - escrito em outro tempo e outro espaço, o qual não pode deixar de contaminar e complicar o tempo-espaço puramente presente que os oradores insistem habitar. Ora, o próprio Handke declara, em entrevista, que seu a principal ideia de suas peças seria "tornar as pessoas cientes do mundo do teatro - não do mundo exterior", ou seja, chamar atenção para o fato de que, no teatro, "há uma realidade teatral acontecendo a cada momento"; nessa realidade teatral, "os objetos são privados de sua função normal na realidade", ganhando "uma função artificial no jogo que eu as forço a jogar" (HANDKE e JOSEPH, 1970: 57). Ao mencionar explicitamente esse princípio teatral, os oradores de Afrontando o público parecem quebrar o encanto da cena, libertando (ou condenando) os participantes para o mundo real. Como eles dizem, a peça "é um prólogo", não "para uma outra peça”, mas "para suas práticas e costumes", incluindo "suas ações" tanto quanto "suas inatividades", ela é um prólogo "para as brincadeiras e a seriedade de suas vidas", incluindo "suas futuras idas ao teatro" (PF: 116). Para tanto, diz o texto, os espectadores logo deverão se mover, se preparar para aplaudir (ou "para não aplaudir"), deixar o teatro e seguir com suas vidas. 
"Mas, antes de partirem, vocês serão insultados", anunciam os oradores (117). Ora, o próprio título da peça, conhecido desde antes de o espectador entrar no teatro, já anunciava o mesmo. Uma ofensa anunciada, para a qual se comprou ingressos, pode ainda ser uma ofensa? Se a peça não tem objetos que pareçam ser outros objetos, nem por isso a ficção pode desaparecer totalmente: o próprio ato central da peça, a afronta ao público, torna-se ficção teatral, como aliás observa o próprio texto: "nós não insultaremos vocês, apenas usaremos palavras ofensivas, as quais vocês mesmos usam" e "Vocês foram informados com antecedência, então não podem se sentir insultados enquanto nós estamos insultando vocês", ou ainda "Nós nos contradizemos com nossos insultos. Nós não nos dirigiremos a ninguém em particular. Nós apenas criaremos um modelo acústico. Vocês não terão que se sentir insultados" (117-8). Nesse sentido, cabe citar a reflexão um pouco longa do filósofo Alexander García Düttman (DÜTTMAN e GRITZNER 2011: 138):

Os performers criam uma incerteza quanto ao que realmente está ocorrendo. Onde está a fronteira entre representar [play] e não representar? Isso é uma peça ou não é uma peça? Os performers são realmente atores? O público deve participar da peça ou não? Na noite de estreia, alguns espectadores chegaram ao palco, provocados pelos atores, mas os atores não se envolveram muito com eles. Como tudo é antecipado, antecipado pelo que está sendo dito no palco, a peça coloca o público em um estado de paralisia quase completa. Não permite nenhum tipo de liberdade do lado da plateia. Isso significa que há um ponto em que o público também pode se tornar completamente indiferente ao que está acontecendo. Quando se assiste à encenação de Peymann, percebe-se que os artistas nunca param de se mover pelo palco e que muitos de seus movimentos foram cuidadosamente coreografados. Mas quanto mais os atores parecem ir e vir, mais o público fica paralisado, e isso é interessante porque mostra que sempre deve haver uma separação e 'distanciação' mínimas na arte, não importa o quanto o público participe e se transforme em uma parte integrante da própria performance, não importa o quanto a noção de uma peça, ou ator, ou a noção de unidade de tempo, lugar e ação seja desfeita. E há uma certa má fé, então, na tentativa de dissimular a necessidade de tal separação. A peça de Handke projeta essa necessidade em uma tela grande, por assim dizer. Existe uma opacidade na arte, uma impossibilidade de participar plenamente, seja porque a obra preenche a lacuna entre a performance e o espectador, como em Publikumsbeschimpfung, ou porque a obra reconhece sua separação do observador, uma separação em que a participação depende. Pertence às regras do jogo de arte que, como espectador, não se pula no palco para resgatar a heroína que se encontra em uma situação perigosa. Eu sei que este jogo pode ser desconstruído, mas no final, uma separação deve permanecer, ou então nada resta, nem mesmo participação. É isso que vem à tona na peça de Handke: os atores, que parecem não respeitar sua separação do público, criam uma barreira intransponível. A barreira, que permite a participação em primeiro lugar, por mais invisível que seja, aparece no palco, fica visível ao ser removida (grifo do original).

Quando então começam as ofensas, nota-se que a princípio elas são, surpreendentemente, elogios, mais especificamente aqueles que se costuma fazer para os atores após uma peça: "vocês foram atores perfeitos" ou "vocês foram como na vida real"; "vocês nos mostraram perspectivas inteiramente novas" e "vocês permitiram que o 
KON, A. S. - Prólogo terminável e interminável

impossível se tornasse possível” (PF: 118-9). A cada parágrafo, a lista de elogios termina com os xingamentos prometidos: "Atuar já estava no seu sangue, seus carniceiros, seus doentes mentais, seus oportunistas, filhos de uma vaca" (119). Aos poucos os elogios cessam e aumentam os insultos, mas cada vez mais elaborados e contraditórios, gerando comicidade: "seus militaristas, seus pacifistas, [...] seus individualistas, seus coletivistas, seus aprendizes de político, espíritos de contradição, [...] seus monstros antediluvianos" (120).

Por fim, os oradores se despedem educadamente, sublinhando ainda mais a ficcionalidade do insulto, mesmo na ausência de uma ficção dramática tradicional: “Aqui vocês foram bem-vindos. Nós lhes agradecemos. Boa noite" (121). Uma gravação com “estrondosos aplausos e assovios selvagens" substitui (ou antecipa) a reação real do público. As afrontas de Handke fizeram enorme sucesso, abrindo o caminho para sua carreira literária e dramatúrgica.

Acusando a si mesmo dá continuidade à forma iniciada na peça anterior, desde as instruções (agora bem mais breves, assim como a peça toda também é mais curta) pedindo "um orador e uma oradora" que "falam seja alternadamente, seja ao mesmo tempo", de modo a "formar uma partitura harmonicamente estruturada", mas esclarecendo também que, "para dizer a verdade, não há papeis” (165). Novamente "a luz permanece ligada na plateia e sobre o palco" (ibid.).

Ao mesmo tempo, já desde o título, a peça se mostra como uma inversão de Afrontando o público, voltando sua agressividade para dentro e não para o espectador. O texto lista uma série de eventos na vida de uma pessoa, desde "Eu vim ao mundo" (detalhado em "Eu fui concebido. Eu fui gerado. Meus ossos se formaram. Eu nasci. Eu entrei no registro de nascimento. Eu cresci”, 166), passando pelo surgimento e desenvolvimento dos movimentos e da consciência, da fala e da linguagem, do conhecimento e da civilidade, da responsabilidade e da obrigação. A listagem exaustiva acaba gerando contradições, indicando que não se trata da narrativa de um eu ficcional consistente, mas da exposição de todas as possibilidades de um "eu gramatical", como analisa Nicholas Hern (1971: 50):

É um tipo de autobiografia abstrata: 'eu' não é uma personagem ou pessoa no sentido convencional de modo algum, fato sublinhado pelas falas sendo partilhadas por duas pessoas, sequer do mesmo sexo. 'Eu' é a palavra pela qual todo mundo se refere a si mesmo, de modo que o 'eu' dessa peça é simplesmente todo mundo; o que explica por que as muitas e variadas ações relatadas mais adiante não podem ter sido realizadas por um indivíduo consistente. Elas são um mosaico da existência de todo mundo. 
KON, A. S. - Prólogo terminável e interminável

Chama a atenção, nesse sentido, que o rol de todos os eventos das vidas de todo mundo se torne uma acusação, e o autor enfatiza a banalidade cômica das atividades elencadas, dando como exemplo "Eu quis abrir as portas puxando-as quando eu deveria empurrá-las", já quase no final da peça (PF: 180); por outro lado, Handke cita como modelos para esse mecanismo moral o confessionário cristão (vários trechos da peça são tirados das Confissões de Agostinho) e a autocrítica stalinista, notando que essa referência trazia uma gravidade para o intuito da obra (HANDKE e OBERENDER 2014: 51). Como se qualquer ação já fosse desde sempre uma infração, e o sujeito portanto desde sempre preso num círculo vicioso de culpa e remissão: "Eu me tornei. Eu me tornei responsável. Eu me tornei culpado. Eu me tornei perdoável. Eu devia expiar. Expiar o crime de ser o que sou" (PF: 169-70). Ao final, resta a conclusão lógica, como uma redução moral de tudo o que foi dito (e supostamente vivido): "Eu não sou como eu fui. Eu não fui como eu deveria ter sido. Eu não me tornei o que eu deveria ter me tornado. Eu não mantive minhas promessas" (181). E, é claro, a listagem precisa incluir a si mesma como última e maior infração: "Eu fui ao teatro. Eu escutei esta peça. Eu falei esta peça. Eu escrevi esta peça" (ibid.).

Predizendo o futuro foi, na realidade, a primeira peça escrita por Handke, ainda em 1965, mas só veio a público graças ao sucesso de seu autor.

Temos novamente quatro oradores, dessa vez recebendo designações individuais, ainda que não constituam personagens: “a, b, c, d", letras que servem para a elaboração de uma combinatória que serve de partitura para as falas (às vezes falam sozinhos, às vezes em duplas, trios, ou todos juntos), criando uma paisagem sonora coral mais do que uma conversa. A peça traz como epígrafe um poema de Osip Mandelstam: “Onde começar?/ Tudo estala, se desloca e cambaleia/ O ar vibra de comparações,/ Uma palavra não convém mais do que uma outra./ A terra zumbe de metáforas...” (57).

Sobre essa estafa com as comparações e metáforas, Handke reflete em um ensaio da mesma época: "De onde vem esse vício de ter que comparar? (E eu chamo isso de vício.) Não virá antes de tudo por causa da incapacidade de primeiro diferenciar singularidades?" (HANDKE 2018: 76). Daí vem o procedimento empregado em todo o texto: criar, a partir de expressões tiradas da linguagem cotidiana e sobretudo lugarescomuns, uma lista de frases tautológicas em que cada coisa só é comparada a ela mesma: “As moscas morrerão como moscas" ou "o castelo de cartas desmoronará como um 
KON, A. S. - Prólogo terminável e interminável

castelo de cartas" $(58)^{5}$. Como se vê na citação, todas as sentenças também são transpostas para o tempo futuro, criando assim a profecia prometida pelo título.

Ora, que visão de futuro pode resultar daí? O próprio Handke diz que "é uma predição que não leva a nada, e, no entanto, de algum modo pressente-se o fim do mundo" (HANDKE e OBERENDER 2014: 166). A estrutura gramatical extremamente simples tornada ladainha ganha ressonâncias bíblicas, num tom ao mesmo tempo poético e apocalíptico, que em algumas das sentenças torna-se explícito também no nível do conteúdo:

As trombetas do juízo final retumbarão como as trombetas do juízo final (PF: $62)$.

E os que foram transfigurados se sentirão como transfigurados.

E os que o horror transformou em estátuas de sal ficarão imóveis como estátuas de sal.

$\mathrm{E}$ os que foram fulminados pelo raio cairão como fulminados pelo raio. [...]

E os que ouviram chamar seus nomes se aproximarão como se chamados por seus nomes (66).

Para o tradutor da edição brasileira, Samir Signeu, "diferente ao que o título da peça possa sugerir, [...] nos deparamos com constatações simplistas, verdades corriqueiras (..) que não apontam para o futuro, mas para o aqui e agora", num "fatalismo exacerbado" (55). Johannes Vanderath (1970: 318) desenvolve mais a leitura, localizando no texto ao mesmo tempo "o tom de prédica e sua paródia [...], como se a cada vez, para o pregador no púlpito, imitando-o, o louco o acompanhasse e devolvesse como um eco a variante paródica de sua proclamação"; daí surgiria "a imagem de um mundo em que catástrofes ocorrerão [...], mas no qual a vida banal e cotidiana seguirá”. Já Nicholas Hern (1971: 48, grifo do original), em sentido oposto, diz que Handke "desvaloriza a indústria da construção de símiles levando-a a sua conclusão lógica em um esforço de restaurar os poderes da simples percepção", de modo a lançar "a ênfase de volta à individualidade, à realidade do próprio fenômeno", como quem insiste que "uma rosa é uma rosa é uma rosa".

Acredito que seria o caso de sugerir uma indecidibilidade entre as duas interpretações: o futuro previsto na peça pode ser tanto a catástrofe, que para Walter Benjamin (2009: 515) significa justamente "que as coisas continuem assim", quanto a

\footnotetext{
${ }^{5} \mathrm{O}$ uso de expressões e lugares-comuns torna bastante problemática a tradução literal pela qual a edição brasileira optou. Uma fala como "Deus viverá na França como Deus na França" perde totalmente o sentido, uma vez que "viver como Deus na França" significa viver confortavelmente, "no bem-bom". Uma solução melhor seria "O paxá viverá como um paxá".
}

Pandaemonium, São Paulo, v. 24, n. 43, mai.-ago. 2021, p. 111-138 
KON, A. S. - Prólogo terminável e interminável

utopia, seguindo "as descrições judaicas do estado messiânico" secundadas por Theodor Adorno (1982: 160): um mundo "que em tudo seria como o atual e só em muito pouco diferiria": "no estado de redenção, tudo é como é e, ao mesmo tempo, inteiramente outro" (17).

Chamando por socorro é a última e menor das "Peças de fala" escritas por Handke no começo de sua trajetória literária, estreando e sendo publicada em 1967. As instruções incluídas na versão impressa resumem bem a proposta:

o papel dos oradores é de descobrir a palavra SOCORRO através do labirinto de um grande número de frases e palavras. elas exprimem foneticamente a necessidade de socorro, fora de toda situação determinada, real. as palavras não são empregadas no seu sentido próprio; elas exprimem apenas a urgência de socorro. enquanto os oradores procuram a palavra "socorro" eles têm necessidade de socorro; quando enfim acham a palavra, não têm mais necessidade da palavra "socorro". [...] quando podem enfim gritar por socorro, eles não têm mais necessidade de gritar. a palavra SOCORRO perdeu o seu significado. [...] e enfim os oradores podem matar a sede bebendo COCA-COLA (PF: 213-4).

A alusão pop ao fim remete a outra, mencionada pelo autor como origem da ideia da peça: a canção “Help!”, dos Beatles (HANDKE e OBERENDER, 2014: 76). Afrontando o público também era dedicada a John Lennon, e Handke cita os Beatles e os Rolling Stones, com sua "intensidade do puro estar-aí no se fazer ouvir, no falar", como fonte tanto para Afrontando... quanto para Acusando a si mesmo (27).

Das quatro peças, essa também é a que mais radicaliza o procedimento de readymade linguístico, consistindo simplesmente numa colagem de frases colhidas da realidade, sendo que ao final das citações vem, como resposta, a palavra "NÃO", sempre em maiúsculas, negando assim que se tenha encontrado o pedaço de fala que se está buscando. As tentativas vão ficando cada vez mais curtas ao longo das cerca de quatro páginas do texto, aumentando assim o ritmo e a sensação de urgência. Assim, a peça abre com: "para concluir, nossos pensamentos irão, mais uma vez, para todos vocês; chamamos e convidamos vocês a procurarem conosco os caminhos de uma compreensão mútua, de um melhor conhecimento uns dos outros, de um diálogo com o coração aberto, de uma existência fraternal numa única comunidade dos homens que abarque verdadeiramente todo o universo: NÃO” (PF: 115). Passa por diversas fórmulas que encontramos no dia a dia, em espaços públicos, jornais etc.: "o general conduziu à vitória as tropas corajosas: NÃO. os talheres foram esterilizados: NÃO." ou "o café da manhã está incluído no preço: NÃO” (215-6). E fecha lançando desesperadamente palavras soltas: “água!: NÃO. daí!: NÃO. perigo de vida!: NÃO. nunca mais!: NÃO. perigo de 
KON, A. S. - Prólogo terminável e interminável

morte!: NÃO. alerta!: NÃO. vermelho!: NÃO. viva!: NÃ̃. luz!: NÃO. atrás!: NÃO. não!: NÃO. lá!: NÃO. aqui!: NÃO. cima!: NÃO. ali!: NÃO. NÃO. NÃO” (218) ${ }^{6}$. Até que finalmente se encontra o que se buscava:

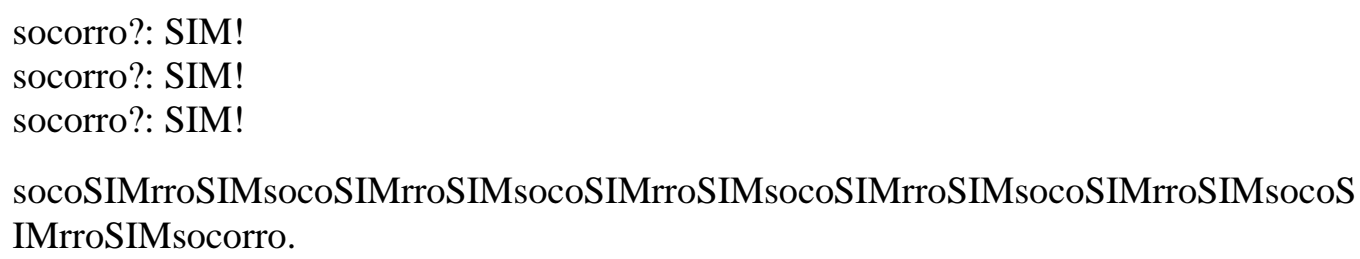

\section{A prisão da linguagem e a torre de marfim}

As obras de Peter Handke, e as peças aqui apresentadas são casos explícitos, têm como interesse maior a investigação dos limites da linguagem em relação à experiência do mundo, restringindo radicalmente o material cênico. Como explica o autor: trata-se de reduzir "a peça a palavras" e as palavras a "apenas citações" sem descrições, de modo que "a única possibilidade para a qual elas apontam é aquela que acontece enquanto as palavras são faladas em cena" (HANDKE e JOSEPH, 1970: 57). Handke argumenta que "quando as pessoas são alienadas de sua linguagem e sua fala, como os trabalhadores de seus produtos, elas são alienadas do mundo também" - caberia ao teatro, portanto, não "dizer a qualquer um como viver", mas antes promover uma "náusea da estúpida ‘linguistificação' [speechification] e a resultante brutalização das pessoas”, comparada pelo autor à náusea sartreana em relação às coisas, e que pudesse ser "um começo de consciência" (61). Mas essa conscientização não é uma lição a ser ensinada a um público alienado por um autor-autoridade consciente. Antes, é um trabalho contínuo sobre si mesmo:

Eu só tenho um tema: ganhar clareza, maior clareza, sobre mim mesmo, passar a me conhecer ou não conhecer, aprender o que faço errado, o que penso errado, o que penso impensadamente, o que falo impensadamente, o que falo automaticamente, o que outros também impensadamente fazem, pensam, falam: ficar atento e chamar a atenção: tornar

\footnotetext{
${ }^{6}$ De novo a tradução literal traz problemas na edição brasileira: perde-se o aspecto sonoro, sendo que várias das últimas palavras usam o som do "h" inicial, e crescentemente do "hi", para se aproximar do almejado "Hilfe" (que, é claro, já está na mente dos espectadores ou leitores). Assim, as últimas palavras e frases experimentadas no alemão são hinlegen, kein halten, halt, feuer, ich ertrinke, ah, ach, nein, hallo, heilig, heilig heilig heilig, hierher, mund zu, heiß, luft, hissen, wasser, davon, lebensgefahr, nie wieder, todesgefahr, alarm, rot, heil, licht, hinten, nicht, da, hier, hinauf e hin.
}

Pandaemonium, São Paulo, v. 24, n. 43, mai.-ago. 2021, p. 111-138 
KON, A. S. - Prólogo terminável e interminável

e tornar-me mais sensível, mais rigoroso, mais preciso, para que eu e também os outros possamos existir de modo mais preciso e sensível, para que eu possa me entender melhor com os outros e lidar melhor com eles (HANDKE 2018: 32).

Não parece ser mera coincidência o fato de que, em 1967, justamente quando Handke terminava suas "peças de fala", no campo da filosofia tenha sido publicado o volume A virada linguística (The linguistic turn), organizado por Richard Rorty (1992), popularizando a ideia de um novo foco do pensamento filosófico, que a partir do século XX passaria a ser centrado na reflexão sobre e a partir da linguagem. Essa mudança costuma ser entendida como abarcando tanto a tradição analítica anglo-saxã antologizada por Rorty (desde Frege, Russell e Wittgenstein), quanto a continental, sobretudo em sua versão francesa estruturalista e pós-estruturalista (começando com Saussure, passando por Levi-Strauss e Foucault, Deleuze e Derrida, e chegando a teóricos americanos como Hayden White e Judith Butler).

Nesse contexto, é compreensível que Handke também comece a observar e criticar o modo como em grande parte dos debates em seu contexto, sobretudo naqueles sobre a arte política, "não se entende que a literatura é feita com a linguagem, e não com as coisas descritas com a linguagem”, negligenciando “o quanto a linguagem é manipulável para fins sociais e individuais", o quanto ela constitui "uma realidade para si" que "não pode ser provada pelas coisas que ela descreve, mas pelas coisas que ela provoca" (HANDKE 2018: 42) - como se os escritores engajados acreditassem "ingenuamente poder olhar através da linguagem para os objetos como através de um vidro" $(37)^{7}$. Para Handke, no campo da práxis social é necessário o engajamento, e especificamente o marxismo, que ele nomeia como "única solução possível para as contradições dominantes" (61). Mas esse engajamento "não pode permanecer inalterado pela forma literária", na qual ele "perde em todo caso seu caráter sério, direto, inequívoco", uma vez que "aquele a quem a mensagem deve ser transmitida não recebe primariamente a mensagem, mas a forma" (52). Assim, "quanto melhor a forma literária [...], tanto mais irônica soará a mensagem em suas mãos"; o que "não significa que pelo contrário [...] [n]um mau trabalho literário a mensagem permaneça séria e eficaz: nesse caso ela não será ironizada, mas indesejadamente e talvez imerecidamente tornada ridícula" (54). Assim como os insultos

\footnotetext{
${ }^{7}$ A comparação é atribuída por Handke a Sartre, que por sua vez a remete a Paul Valéry: "A prosa é antes de mais nada uma atitude do espírito; há prosa quando, para falar como Valéry, nosso olhar atravessa a palavra como o sol ao vidro" (SARTRE, 2004: 19). Handke (2018: 48) diz ainda que esse erro de Sartre está relacionado a outro: a separação de prosa e poesia, que segundo o escritor austríaco "pertence ao século dezenove".
}

Pandaemonium, São Paulo, v. 24, n. 43, mai.-ago. 2021, p. 111-138 
KON, A. S. - Prólogo terminável e interminável

de Afrontando o público são insultos ficcionais, assim como "uma cadeira em cena é uma cadeira de teatro" necessariamente (HANDKE e JOSEPH 1970: 57), o engajamento da cena será sempre um engajamento encenado, representado, meras palavras que "não apontam mais para as coisas, mas para si mesmas" e com isso "perdem sua inocência" (HANDKE 2018: 55). Em seu gosto pela polêmica, Handke não hesita em afirmar sua posição supostamente antipolítica: "Então é de bom grado que eu me deixo ser chamado de habitante da torre de marfim" (32).

Não admira que a "virada linguística" tenha sido alvo de diversas críticas por parte de pensadores ligados à tradição marxista. Para Terry Eagleton (2016: 123-4), é preciso combater o "idealista linguístico que se encontra em toda parte na cultura pós-moderna", recusando a ideia de uma linguagem que “constrói’ a realidade” e assim "nos aparta dela". Essa imagem de separação, bem como a de fechamento sugerida pela torre de marfim adotada por Handke, ganha corpo na ideia de "prisão da linguagem" elaborada por Fredric Jameson (1972: ix), para quem "há uma profunda consonância entre a linguística como método e aquele pesadelo sistematizado e desencarnado que é nossa cultura hoje", onde se vê "o espetáculo de um mundo do qual a natureza enquanto tal foi eliminada, um mundo saturado de mensagens e informação, cuja rede intricada de mercadorias pode ser vista como o protótipo mesmo de um sistema de signos". Segundo o pensador americano, se o conceito estruturalista de signo "proíbe qualquer investigação da realidade além dele" (106), então “nossa possessão pela linguagem, que nos 'escreve' mesmo quando nos imaginamos escrevendo-a, não é tanto uma libertação final do subjetivismo burguês, mas antes uma situação limitadora contra a qual temos que lutar a cada instante" (140).

Esse tipo de crítica não deixou de ser lançado também contra textos e experimentos que, como os de Handke (que afinal de contas era adversário declarado do teatro político de sua época), punham em cena não uma figuração do mundo fora do teatro, mas um espaço hermeticamente fechado no qual a linguagem volta-se sobre si mesma. Para essas obras, aproveitou-se o termo "pós-moderno", que com isso deixa de lado sua complexidade analítica para se ver reduzido a pouco mais do que mero xingamento. No entanto, poderíamos lembrar que Jameson também diz que "uma crítica genuína" desse pensamento centrado na linguagem, longe de poder ser uma recusa abstrata dele, "nos compromete a galgar nosso caminho através dele completamente de modo a emergir, do outro lado, em uma perspectiva filosófica totalmente diferente e 
KON, A. S. - Prólogo terminável e interminável

teoricamente mais satisfatória" (vii). De modo semelhante, podemos considerar que um teatro que se queira verdadeiramente político precisa levar a sério o desafio colocado nas "peças de fala" do escritor austríaco. Se quiser ir além delas, precisará adotar decididamente uma crítica das posições e obras que ficam aquém delas, acreditando que os argumentos teóricos marxistas reproduzidos acima são suficientes para autorizar que se siga fazendo o mesmo teatro engajado de antes. Mas estar à altura da provocação handkeana requer compreendê-la, a começar pelo contexto histórico que a produziu tarefa que nenhuma política consequente poderá ver como supérflua.

Um trabalho recente de Marjorie Perloff pode nos dar um valioso ponto de entrada nesse contexto ${ }^{8}$. Para essa importante teórica e crítica, contra uma história literária que prioriza sempre as versões francesa, anglo-americana e alemã do Modernismo, seria o caso de voltar a atenção para aquilo que ela nomeia "Austro-Modernismo", que para ela "parece cada vez mais importante para uma compreensão de nossos próprios valores artísticos e culturais um século depois", uma vez que "antecipa tão estranhamente muito do caráter sombrio e cínico - mas também do humor intenso - da nossa própria cultura desiludida do século vinte e um" (PERLOFF 2016: xiv). A pensadora recusa a ideia de que essa variante austríaca do modernismo seria "uma versão mais fraca da formação intelectual forte da República de Weimar", afirmando antes que ela é "meramente diferente" (13, grifo do original). E isso devido à especificidade histórica de seu lugar de nascimento: o recém desintegrado Império Austro-Húngaro: “o trauma da guerra seguido pela repentina e radical dissolução das entidades geográficas nas quais esses escritores nasceram criou um modernismo profundamente cético e resolutamente individualista muito menos ideologicamente carregado do que sua contraparte na Alemanha", onde surgiu tanto o teatro de Brecht quanto a filosofia de Heidegger, nenhum dos quais "parece ter tido muito apelo para o mundo irônico, satírico, sombriamente humorado, erótico - e muitas vezes ligeiramente místico - da Áustria pós-imperial” (4-5).

Naquelas circunstâncias, argumenta ainda Perloff, “mudança veio a significar não revolução política, a mudança da ordem social ou política, mas uma mudança de consciência", um pouco como vimos Handke falar do seu trabalho literário sobre si; contudo, "a recusa de engajamento político direto não excluiu o que foi uma presciência extraordinária entre escritores austro-modernistas" (5). Ao mesmo tempo, o alemão foi

\footnotetext{
${ }^{8}$ Perloff fez toda sua carreira nos EUA, mas nasceu em Viena, de onde sua família de judeus seculares fugiu quando ela tinha apenas seis anos, por conta da anexação da Áustria pela Alemanha nazista.

Pandaemonium, São Paulo, v. 24, n. 43, mai.-ago. 2021, p. 111-138
} 
KON, A. S. - Prólogo terminável e interminável

"a língua nativa mas também escolhida" para muitos desses escritores (nascidos em diferentes partes de um império poliglota), tornando a linguagem "inabitualmente consciente de si - objeto de contemplação mais do que meio de comunicação" (11-2). Perloff cita Karl Kraus, para quem "confrontar os enigmas das regras da linguagem, as cenas de seus perigos, é uma mania mais admirável do que a loucura que pensa poder controlar a linguagem" (39). Que Handke seja herdeiro desse Austro-Modernismo - que inclui Freud e Wittgenstein, Kraus, Robert Musil e Joseph Roth, Paul Celan e Ingeborg Bachmann, Elias Canetti e Thomas Bernhard - é não apenas evidente, mas esclarecedor, além de dar um fundamento histórico às frequentes aproximações entre suas peças e o pensamento de Wittgenstein, sob cujo signo todos esses autores teriam escrito, conscientemente ou não, de acordo com Perloff. Para Richard Gilman, por exemplo, "Handke escreveu peças (bem como alguma ficção e poesia) que avançam uma distância extraordinária no sentido de implementar em termos artísticos o esboço de Wittgenstein da tarefa e método do filósofo" (GILMAN 1999: 269).

Ora, Wittgenstein também é um dos filósofos da linguagem que pode auxiliar na recuperação da "virada linguística" para um pensamento político materialista, pelo menos de acordo com Terry Eagleton (2016: 123-4) "Wittgenstein pode ver a linguagem como atividade autônoma", mas, diferente do que pensariam os idealistas pós-modernos, para ele "são os homens e mulheres que a constroem com seus projetos práticos, e a linguagem é tecida nesse empreendimento. É no nosso falar que essas formas de atividade são sedimentadas", e nesse sentido a linguagem é uma prática coletiva e histórica. É nisso que também insiste o pensador francês Jean-Jacques Lecercle (2006) ao tentar propor uma filosofia da linguagem contra a ênfase sincrônica (ou seja, estável e temporalmente imóvel) em Saussure e todos os que o seguiram; que esse projeto esteja inserido em "uma luta contra a filosofia dominante no campo da linguagem", a qual "articula a posição liberal em relação à filosofia da linguagem" $(12)^{9}$, indica o papel que as peças de Handke podem desempenhar nesse caminho de pensamento. Pois, e é o que tentarei mostrar, de certo modo é contra esse mesmo inimigo que elas se voltam.

\footnotetext{
${ }^{9}$ Vê-se importância que Lecercle confere ao projeto na avaliação de que as "recentes e espetaculares derrotas do movimento dos trabalhadores em escala mundial se deveram em não pouca medida ao fato de que a classe inimiga sempre venceu a batalha da linguagem e o movimento dos trabalhadores sempre negligenciou esse terreno" (LECERCLE 2006: 12-3).
}

Pandaemonium, São Paulo, v. 24, n. 43, mai-ago. 2021, p. 111-138 


\section{As funções e as disfunções da linguagem teatral}

Conforme analisa Michael Shapiro (1985: 407-8), as peças de Handke mostram "a autoridade imanente e não-reconhecida em práticas tradicionais de fala", bem como "o dilema [...] de não ter nenhuma identidade senão aquela que é emprestada pelos donos da linguagem"; nesse sentido, o espectador precisa "se tornar ciente do que 'faz sentido' e como", e ao mesmo tempo se acostumar "com o nonsense (sem sentido) para ver como o que é sensato envolve um tipo de submissão a identidades que servem à autoridade existente". De modo semelhante, Rainer Nägele (1981: 225) observa em Handke um “mal-estar [Unbehagen] na linguagem", remetido a um modo de coerção que seria próprio às "cadeias significantes, nas quais um significante puxa e chama pelo outro": suas peças encenariam o fato de que "onde se fala, onde há e agem signos, aí estão em jogo a violência, a dominação e a coerção". Ora, o modo fundamental como essa coerção se faz passar por um funcionamento natural da linguagem é justamente aquela posição liberal que Lecercle apontava em um pensamento dominante, na verdade uma "ideologia encarnada em uma fórmula simples: 'a linguagem é um instrumento de comunicação"” (2006: 64). Essa filosofia hegemônica e naturalizada poderia ser desdobrada, segundo esse pensador, em alguns princípios norteadores: imanência, funcionalidade, transparência, idealidade, sistematicidade e sincronia (67-9). Relidos à luz das "peças de fala", esses conceitos podem nos revelar seus limites e contradições.

Já vimos como Handke questiona o princípio de transparência - visto por ele como pressuposto de grande parte da arte engajada do seu tempo, a qual se torna portanto passível de crítica em sua dimensão ideológica - segundo o qual a linguagem como instrumento de comunicação tem como característica principal "sua capacidade de se fazer invisível” (68), como o vidro de Sartre e Valéry. Ou, na sugestiva imagem fornecida por Lecercle, "o que me interessa é bater no prego: o formato e cor do cabo do martelo têm pouca importância para mim"; como uma ferramenta, "tudo na linguagem deve ser adaptado para a transmissão fácil e eficiente de informação" (ibid.). Se daí resulta que "os momentos quando ela é chamada de volta à nossa atenção, como no texto poético, devem permanecer estritamente limitados a jogos de linguagem marginais e especializados" (ibid.), é porque esses textos - como as peças que aqui nos ocupam - trazem em si um contraprincípio que aponta para uma outra filosofia da linguagem: o "princípio de opacidade", que revela essa transparência da linguagem e do sentido como ilusão (71). 
KON, A. S. - Prólogo terminável e interminável

Ao partir de ready-mades linguísticos, as peças de fala mostram bem como "dizemos aquilo que nossa linguagem nos permite dizer; falamos com - mas também contra - nossa linguagem", numa constante negociação cheia de concessões, num compromisso "entre aquilo que gostaríamos de dizer e aquilo que descobrimos (às vezes para nosso horror) que realmente dissemos" (ibid.). Por mais que os oradores de Afrontando o público repitam de diversas maneiras que "nós não representamos nada e não somos outros que nós mesmos" e "nem mesmo representamos nós mesmos" (PF: 114), mesmo que a linguagem teatral seja despida de seus códigos dramáticos, o próprio fato de isso ser dito e encenado, de ser linguagem (seja verbal ou cênica), compromete o conteúdo, pois pelas frestas da palavra se infiltra a representação. Afinal, não é possível concordar que "aqui nada é inventado" e "nada é imitado" (ibid.), no mínimo sabemos que se trata de um texto redigido por um escritor e decorado pelos atores-oradores. Por mais que as tautologias de Predizendo o futuro a rigor não comuniquem nada, sua cantilena produz a ambígua imagem, utópica ou catastrófica, do fim dos tempos.

Mas talvez o princípio em jogo de modo mais radical nas obras aqui discutidas seja o de funcionalidade. Para expô-lo, Lecercle (op. cit.: 68) remete às muito conhecidas funções da linguagem elencadas por Roman Jakobson, não por acaso "deduzidas de seu diagrama da comunicação". Gostaria de mostrar como cada uma das quatro peças de Handke - tenha ele elaborado essa relação intencionalmente ou não - trabalha, ou antes joga, com uma das seis funções (o que resulta, a princípio, na exclusão de duas, o que também apontarei como significativo).

Assim, Afrontando o público elabora claramente "a orientação para o DESTINATÁRIO, a função CONATIVA” de Jakobson (1992: 125). Mas, se ela "encontra sua expressão gramatical mais pura no vocativo e no imperativo", saltaria aos olhos num primeiro momento a ausência ou raridade de ambos no texto de Handke, onde abundam as "sentenças declarativas" de que aquelas "diferem fundamentalmente" por não poderem "ser submetidas à prova de verdade" (ibid.). Vejamos um trecho logo no início da peça: "Vocês não pensam nada. Vocês não pensam em nada. Nós pensamos por vocês. Vocês não aceitam que nós pensemos por vocês. Vocês se sentem desinibidos. Seus pensamentos são livres" (PF: 93). Não é difícil perceber que, por trás de aparentes constatações, podemos ler sugestões mais ou menos forçosas que poderiam ser traduzidas como: "não pensem", "deixem que pensemos por vocês", mas também "não aceitem que pensemos por vocês" e "libertem seus pensamentos". Transcritos assim, esses 
KON, A. S. - Prólogo terminável e interminável

imperativos revelam uma equivalência além da aparente oposição: "deixe que eu pense por você" e "pense por si mesmo", como ordens, são praticamente iguais, na medida em que em ambos os casos é o enunciador que determina o ato do pensamento, qualquer que seja seu conteúdo. Ora, não é justamente essa paradoxal igualdade que está na base do teatro político tão criticado por Handke? Seja quando oferece palavras de ordem e doutrinas, seja quando pretende apenas colocar questões para que o espectador as responda por conta própria, aprendendo assim a pensar criticamente, essa cena determina seu efeito político como uma via de mão única, em que cabe ao receptor seguir aquilo que foi determinado pelo artista, ainda que seja sua suposta emancipação. O intuito de despertar no público um senso crítico ativo pressupõe sua ausência na situação inicial, no limite implica apontá-lo como passivo, ignaro, alheado. Cabe lembrar como o filósofo Jacques Rancière (2008: 36) resume a atitude desse teatro político: "trata-se sempre de mostrar ao espectador o que ele não sabe ver e de lhe envergonhar por aquilo que ele não quer ver". Vemos assim como constatações se transformam em ordens, e as ordens em insultos - aí, muito mais do que na paródia de xingamento com que a peça termina, está a verdadeira afronta ao público.

De modo semelhante, é evidente que Acusando a si mesmo investiga aquilo que Jakobson (1992: 123-4) chamou de 'função EMOTIVA ou 'expressiva', centrada no REMETENTE", visando "uma expressão direta da atitude de quem fala em relação àquilo de que está falando". Também semelhante é o tom a princípio objetivo das declarações dos dois oradores, como se meramente constatassem as ações executadas e enumeradas. Sua acumulação, porém, ainda por cima somada à informação imperiosa dada pelo título da peça, tinge todas as sentenças de uma certa culpa, explicitando que alguma regra ou expectativa foi quebrada. Ao mesmo tempo, é interessante notar que, para Jakobson, esse uso da linguagem "tende a suscitar a impressão de uma certa emoção", mas que esta não deve ser entendida como necessariamente autêntica, podendo ser "verdadeira ou simulada" (ibid.). Se a culpa é um efeito da linguagem, resultado de se falar em primeira pessoa, tanto faz se ela é "realmente sentida" pelo enunciador: importa apenas que ele cumpra com o ritual da expiação, como nos modelos da autocrítica e da confissão citados por Handke. Na verdade, o próprio eu é um efeito da repetição da palavra "eu" (lembremos que os enunciados da peça são contraditórios e não se referem a uma personagem coesa), e tudo aquilo que ele faça ou fale (ou deixe de fazer ou falar) soará como expressão dessa subjetividade que, pelo contrário, é construída por seus gestos e 
KON, A. S. - Prólogo terminável e interminável

falas: assim, "Eu me expressei através dos movimentos" e "através dos meus atos", bem como "da minha imobilidade" e "inatividade", e finalmente "Eu me desmascarei em cada um dos meus atos", isto é, "Eu demonstrei em cada um dos meus atos o respeito ou desprezo às regras" (PF 170-1). Apresentada em uma peça de teatro, essa lógica ganha mais uma camada de leitura possível. Assim como em Afrontando o público todo direcionamento ao espectador revelava um juízo sobre ele, em Acusando a si mesmo vemos como toda construção cênica de um Eu enunciador impõe sobre ele o lugar de réu, de infrator, pelo menos em potencial. Num palco-tribunal (imagem recorrente do teatro político) não pode haver inocentes.

Esse modo de leitura ganha interessantes contornos ao ser testado no caso de Predizendo o futuro, onde localizamos aquele "pendor para o referente", aquela “orientação para o CONTEXTO” que Jakobson (1992: 123) chama de "função REFERENCIAL, 'denotativa', 'cognitiva"'. Para o teórico russo, essa é justamente "a tarefa dominante de numerosas mensagens", o que podemos ler como: aquela em que a ideologia da comunicação tem lugar de modo mais perfeito; eis porque Lecercle (2006: 68) diz que ela tem lugar "essencial ou primário" em uma hierarquia observável entre as funções. Central é a troca de informações sobre o mundo. O que acontece, porém, quando essa função é reduzida à pura tautologia? O que é comunicado numa frase como "O amanhã virá tão certo como o amanhã" (PF: 66)? A rigor, nada além daquilo que sua própria forma diz: que uma coisa é e será essa coisa, que $\mathrm{A}=\mathrm{A}$, que o mundo é como ele é. O que parece nos confinar a um princípio de imobilismo e conformidade. Mas não seria esse outro contratempo de um teatro político preocupado demais em retratar o funcionamento do mundo? O princípio realista a que a maior parte das obras engajadas obedecem não corre o risco de simplesmente reafirmar e repetir aquilo que todos (espectadores e artistas) já sabem sobre o terrível estado de coisas, servindo mais para prender-nos a ele do que para nos libertar de suas amarras? Novamente poderíamos remeter a Rancière, sobretudo à sua crítica da sociologia: por um lado, "para esta perspectiva sociológica, a política é o resultado de uma análise das condições sociais, mas como há tantas condições a ser analisadas, nunca termina e, finalmente, nada acontece"; ao mesmo tempo, esse "pensamento sociológico dominante", ao postular a existência de "um estado normal das relações sociais que produz humilhação, injustiça, dominação, desilusão", ao explicar bem demais "como e por que o sistema absorve as pessoas, esmaga e humilha os que querem se rebelar, e inclusive faz com que percam seu objetivo", acaba 
KON, A. S. - Prólogo terminável e interminável

fazendo dessa insurreição um acontecimento tão excepcional que se torna impossível ou quase (RANCIÈRE e MoRENO 2018). Quando, porém, lemos em Handke frases como "A realidade se tornará realidade" e "A verdade se tornará verdade" (PF: 67), podemos ouvir ressoar em seu tom poético e profético justamente o oposto dessa pura identidade que elas pareciam querer comunicar: se a realidade se tornará realidade, é porque ela ainda não é de fato real; se a verdade se tornará verdade, é porque a verdade hoje é uma mentira. Como no verdadeiro pensamento dialético, é a contradição que permite a transformação e a mobilidade. Contudo, sem uma linguagem capaz de exprimir essa contradição naquilo que ela tem de mais aparentemente ambíguo e não evidente, ou seja, sem uma enunciação estética que torne sensível a contradição como contradição, ela pode ser facilmente reduzida ao hábito do conhecimento sociológico estéril.

Jakobson (1992: 125-6) esclarece que um modelo tradicional da linguagem “confinava-se a essas três funções - emotiva, conativa e referencial - e aos três ápices desse modelo - a primeira pessoa, o remetente; a segunda, o destinatário; e a "terceira pessoa" propriamente dita, alguém ou algo de que se fala”. O que pode ser uma explicação para Chamando por socorro ser não apenas a última e menor das peças, mas ter sido inclusive escrita, encenada e publicada depois que as três anteriores já haviam sido reunidas em livro. Nem por isso ela deixa de fazer parte do todo, uma vez que "certas funções verbais adicionais podem ser facilmente inferidas desse modelo triádico", a começar por aquelas mensagens "que servem fundamentalmente para prolongar ou interromper a comunicação, para verificar se o canal funciona [...], para atrair a atenção do interlocutor ou afirmar sua atenção continuada", correspondendo a um "pendor para o CONTATO ou [...] para a função FÁTICA” (126). O linguista fornece exemplos, desde “fórmulas ritualizadas” banais como um “Alô, está me ouvindo?” falado ao telefone “e, no outro extremo do fio, 'Hm-hm!'”, até a “dicção shakespeariana 'Prestai-me ouvidos!'” (ibid.). Em sua pura afirmação da vontade ou necessidade de comunicação, sem qualquer informação a ser transmitida, essa função estaria presente tanto em animais quanto em crianças pequenas, antes das demais. Eis que vemos, na peça de Handke, inúmeros pedaços de falas cotidianas perderem todo conteúdo referencial, tornando-se meros meios para tentar dizer algo, como nos "diálogos inteiros cujo único propósito é prolongar a comunicação" de que fala Jakobson (ibid.). Mas aqui esse algo também não é um conteúdo, mas uma relação, uma forma de contato: socorro ou ajuda. Mais uma vez proponho que podemos ler a peça como um comentário sobre o teatro como um todo, e 
KON, A. S. - Prólogo terminável e interminável

sobretudo o teatro político: com toda sua pretensão - de representar, compreender, julgar, criticar, ensinar, libertar, despertar, enfim, de operar - ele poderia ser visto (de modo um tanto simplificador, é claro) como um mero desejo de encontro, o que equivale a postular a falta real desse encontro. Falta que sua operação crítica só faz reforçar: não há contato real possível num teatro que se coloca como um tribunal onde todos são julgados e como uma escola onde o artista deve ensinar algo para o espectador. Mas quando os oradores encontram a palavra "socorro", já não precisam dela. A busca por ajuda era idêntica à busca pela linguagem que permite exprimir a busca por ajuda. Quando as "peças de fala" dão nome ao funcionamento habitual da linguagem, ao mesmo tempo elas o ironizam, de modo que ele pode ser suspenso, tornar-se inoperante. Ou, para usar um vocabulário bastante em voga no encontro dos estudos teatrais com a linguística: ao encenar a performatividade da linguagem cotidiana, Handke não a alimenta num suposto "teatro performativo" (como quer, por exemplo, Fischer-Lichte [2004]) mas a desfaz temporariamente, a coloca num estado estético de suspensão a que Lehmann (a partir de Hamacher [1997]) chamou de aformativo. Pois o teatro trabalha com "a dúvida sobre o fato de algo ter sido representado ou não", com "a incerteza quanto ao fato de se tratar ou não de um ato", contrapondo "a cada tese, cada posição, cada obra, cada sentido uma indeterminação e um potencial cancelamento" (Lehmann 2011: 417).

Ora, o "princípio de disfuncionalidade" é justamente mais um dos contraprincípios postulados por Lecercle (2006: 70, grifo do original): a linguagem não como "instrumento à disposição do falante', mas como "uma experiência e uma atividade", um espaço onde "se entra" e "se habita". Assim, estamos prontos para encontrar as duas funções jakobsonianas que ficaram excluídas: a "função METALINGUÍSTICA (isto é, de glosa)" em operação "sempre que o remetente e/ou o destinatário têm necessidade de verificar se estão usando o mesmo código" e "o pendor para a MENSAGEM como tal, o enfoque da mensagem por ela própria" que constitui a “função poética da linguagem" (JAKOBSON 1992: 127-8, grifos do original). Ora, fica claro que elas não estão, na verdade, excluídas do projeto de Handke, mas combinadas e generalizadas em sua crítica literária da própria linguagem. Juntas, elas se transformam: "verificar se se usa o mesmo código" passa a incluir verificar os limites e possibilidades desse código, bem como as frestas pelas quais ele pode ser subvertido; "a mensagem como tal" e "por ela própria" transforma-se na ausência mesma de mensagem. Universalizadas, as duas funções se impõem sobre as outras quatro em cada uma das 
KON, A. S. - Prólogo terminável e interminável

peças debatidas, interrompendo e contrariando esteticamente a visão ideológica da linguagem segundo a qual, de acordo com Lecercle (2006: 68), "qualquer fenômeno linguístico que não se resume a essa instrumentalidade ou intencionalismo (o que eu digo é o que eu quero dizer, o sentido da enunciação é uma função do sentido pretendido pelo falante) será desconsiderado como ruído, no sentido literal do termo - uma contingente e (espera-se) temporária dificuldade de comunicação".

Agora podemos avaliar rápida e conjuntamente os princípios restantes da ideologia liberal da linguagem denunciada por Lecercle. Segundo eles, a linguagem só pode ser entendida considerada em si, "separada de todos os outros fenômenos" e "abstraindo de qualquer contato entre linguagem e mundo" (princípio da imanência, 678); ela é "um sistema abstrato e ideal realizado na fala ou uma competência biológica realizada na performance" (princípio da idealidade, 69); é ainda "um código fixo", "um conjunto de regras" contrário à fala "infinitamente variável e caótica" (princípio de sistematicidade, 69); finalmente, esse sistema "é imune, se não à mudança, então pelo menos à história" - a linguagem até pode mudar, mas não historicamente, e sim passando de um sistema fechado para outro (princípio de sincronia, 69). Contra essa visão, as peças de Handke apresentam uma linguagem não apenas opaca e disfuncional, mas histórica, material, não-imanente (o que não significa transcendente) e apenas parcialmente sistemática (70-2).

Ou seja, (1) a linguagem é resultado da sedimentação de regras, convenções, máximas e sentidos: Lecercle nota que "as únicas metáforas realmente vivas são metáforas mortas, pois elas são as que a comunicação linguística adotou e reutiliza $a d$ infinitum" tornando-se assim "tão indetectáveis quanto as pressuposições, tão naturalizadas quanto as tautologias" (219); já as tautologias de Predizendo o futuro, justamente explicitando o caráter clichê e morto dessas metáforas, devolve-as um outro tipo de vida. A linguagem é (2) inseparável de sua realização, de sua força ilocucionária ou performativa: dizer "eu" na confissão de Acusando a si mesmo é produzir um "eu" como locus de culpa. Também é (3) inseparável do resto da atividade humana, por mais que seja reduzida ao seu mínimo: em Chamando por socorro, falar o que quer que seja serve menos para transmitir um conteúdo do que para nos remeter a uma situação social almejada. E (4) a linguagem inclui espaços de regularidade e espaços de jogo agramatical e inventivo: tudo aquilo que os oradores comunicam em Afrontando o público é tanto uma tentativa de comunicar seriamente certas verdades - e, nisso, é falso - quanto um 
KON, A. S. - Prólogo terminável e interminável

jogo poético com as possibilidades imaginadas de um novo teatro, talvez impossível - e, justamente nisso, é verdadeiro num sentido mais amplo. Eis porque tem de ser ao mesmo tempo mentira e verdade quando eles dizem: "Vocês não precisam ser os juízes da peça. Vocês não são mais tratados como espectadores, a quem nós podemos falar apartes. Isto não é uma peça. Não existem apartes aqui. Nada do que acontece aqui é planejado como um apelo a vocês. Isto não é uma peça” (PF: 94).

\section{A aparência do conceito}

Rainer Nägele (1981: 221) propõe três pontos de aproximação entre o teatro de Handke e o de Brecht, apesar das condenações explícitas lançadas pelo austríaco contra o alemão. Primeiro, visível desde o título Afrontando o público, "aquele ponto que Walter Benjamin via como cerne do teatro épico: a relação com o público"; mas, como vimos, "ao contrário da expectativa do título, de modo algum a peça é um mero texto de choque e xingo" (ibid.), e diversos comentadores enfatizam que a peça não propõe nenhum contato real com o espectador para além do endereçamento (como vimos com García Düttman $)^{10}$. Segundo, "a crítica ao teatro como instituição": assim como as "peças de fala", a cena dialética brechtiana é muito menos "teatro como espaço de significado", do que lugar de crítica e experimentação estéticas dos limites da linguagem cênica, assumindo plenamente seu caráter de jogo não-sério (ibid.) ${ }^{11}$. Finalmente, a consciência do próprio limite, pois a crítica ao teatro brechtiano seria "não tanto direcionada contra o autor quanto contra a captura institucional e neutralização política de seus textos” (ibid.), mas Handke também sabe que suas próprias experimentações passarão pela mesma institucionalização: por isso diz que, uma vez terminado um texto, "o método da próxima peça vai consistir em refletir sobre os métodos de até aqui e, usando-os, inutilizá-los para

\footnotetext{
${ }^{10}$ Para Nikolaus Müller-Schöll (2018: 73), a peça "aparece em retrospecto [...] como paradigmática da ruptura política, teórica e da prática do teatro dos anos 1960 - bem como de seus limites": por um lado, é "um ponto de virada sintomático na história das relações entre atores e observadores do teatro"; por outro lado "a rampa entre atores e públicos é respeitada, mesmo que o endereçamento ao público - de todo modo meramente imaginário - no texto pareça simbolicamente ultrapassá-la" (76).

${ }^{11}$ Brecht teria confessado ao amigo Benjamin (2010: 25): "Frequentemente eu me imagino sendo interrogado por um tribunal: 'Pode explicar isso? Você está falando sério?' Eu teria então que reconhecer que não levo as coisas completamente a sério. Eu penso demais também em questões artísticas, no que funciona no teatro, para ser completamente sério. Mas tendo respondido com um não a essa pergunta importante, passo então a uma colocação ainda mais importante: que o meu comportamento é de fato lícito". A imagem do tribunal poderia nos remeter de volta a Acusando a si mesmo e nossa leitura da peça em relação ao teatro político.
}

Pandaemonium, São Paulo, v. 24, n. 43, mai.-ago. 2021, p. 111-138 
KON, A. S. - Prólogo terminável e interminável

o teatro" (HANDKE 2018: 33-4). Cada método, depois de encontrado, torna-se parte de um arquivo morto, precisando ser deixado para trás na busca de um novo (que se trate de um novo método e não um novo produto é essencial para não se recair numa lógica da "novidade" como mercadoria). Pois "percebi que as possibilidades no teatro não são limitadas, mas que sempre há uma possibilidade a mais do que eu tinha pensado" (34).

Essa tripla ineficácia - primeiro porque toda relação com o público é uma nãorelação, segundo pelo caráter de jogo intrínseco à cena em oposição à seriedade da práxis social, e finalmente pela institucionalização que neutralizaria com o tempo até mesmo os procedimentos estéticos empregados - é central para localizar as peças de Handke não apenas dentro de uma compreensão histórica do teatro contemporâneo, mas como pivôs da transformação histórica que o engendrou.

Assim, se o teatro contemporâneo é pós-dramático, como quer o teatrólogo HansThies Lehmann, é porque ele não precisa mais se reduzir ao drama com sua complexa composição de texto, diálogo, situação, figuras e ações ficcionais (o que não significa que ele não possa se valer de todos esses elementos), podendo pisar as tábuas do teatro e tomar como base a própria situação teatral. Com isso há a tendência (que Lehmann localiza mais em encenações do que em textos) a um "recuo do eixo intracênico em prol do eixothéatron" ou extracênico, isso é, "um eixo ortogonal que diz respeito à comunicação entre o palco e o local da plateia, diferenciado (real ou estruturalmente) do palco" (2011:211). De fato, em seu livro mais célebre Lehmann cita explicitamente as peças de fala de Handke como pertencendo "à genealogia do teatro pós-dramático", à medida que nelas "o teatro se reduplica, cita seu próprio discurso", e "a problematização da 'realidade' como realidade de signos teatrais se torna uma metáfora para o esvaziamento das figuras de linguagem, que se dobram sobre si mesmas" sem fazer "referência a um determinado significado", deixando o público "perplexo diante da alternativa de pensar sobre o nada em face dessa ausência ou ler as próprias formas, os jogos de linguagem e os atores” (91). Porém, "na medida em que ex negativo faz de todos os critérios do teatro dramático seu tema, [Handke] ainda permanece preso a essa tradição", ainda que "ao mesmo tempo ele aponta para o futuro do teatro após o drama" (ibid.) ${ }^{12}$.

\footnotetext{
${ }^{12}$ Müller-Schöll (2018: 77) segue a linha de seu professor Lehmann: "se a peça é parte inevitável daquela ruptura observável no teatro nos anos 1960, a sequência da 'crise do drama' constatada por Szondi e ao mesmo tempo o começo do 'teatro pós-dramático' [...], por outro lado à distância também fica claro que ela ainda está apenas no seu começo. Lemos uma abundância de negações, que de certo modo simultaneamente pressupõe justo aquilo que negam, deixam-no reviver como possível".
} 
KON, A. S. - Prólogo terminável e interminável

Se além de pós-dramático o teatro contemporâneo é pós-vanguardista, como sugere o filósofo frankfurtiano Christoph Menke (em diálogo crítico e produtivo com Lehmann), é porque em sua base ou princípio "encontra-se a experiência do fracasso das vanguardas históricas", ou seja, o "reconhecimento da diferença estrutural que separa o jogo da ação, o teatro da práxis" (MENKE 2010: 16-7). Mas esse teatro não necessariamente desiste de seu propósito político em prol da "liberação meramente estética do jogo teatral", agora "livre de finalidades externas de representação e práxis", tornando-se "um teatro que não pode compreender a si mesmo, pois não pode conter e expressar a própria precondição: a sua relação com a práxis" (17-8). Contra essa cena puramente estética, Menke defende peças que refletem em sua própria forma esse fracasso e essa ineficácia, bem como sua própria persistência; apesar de não estar entre os autores citados pelo filósofo (Beckett, Heiner Müller e Botho Strauss), Handke merece figurar nesse panteão (ver também MENKE 2008).

Finalmente, eu gostaria de acrescentar que o teatro contemporâneo é pósconceitual. Nisso, sigo a análise que o pensador americano Peter Osborne propôs no campo das artes visuais, onde parece caber de modo mais natural. Afinal, não há algo que se costume chamar ampla e consensualmente de "teatro conceitual" (apesar de alguns pesquisadores poderem usar individualmente esse termo) como há “Arte Conceitual” ou, com menor respaldo, "Escrita conceitual" - que Marjorie Perloff (2018: 33) localizou entre o readymade duchampiano e o pensamento wittgensteiniano sobre a linguagem: "a mais alta arte" para esses contemporâneos seria "aquela que de algum modo nos apresenta a própria vida, como de fato é vivida, transmitida na 'linguagem da informação' mas enquadrada de modo a torna-la outra, não familiar, estranha", isto é, "não usada no 'jogo de linguagem de dar informação", como vimos na análise das funções jakobsonianas da linguagem e seu deslocamento pelas funções metalinguística e poética. É nesse sentido que acredito que o conjunto das "peças de fala" aqui analisado - concluído dois anos antes da publicação do célebre ensaio-manifesto “A arte depois da filosofia” por Joseph Kosuth, não por acaso também trazendo a marca decisiva do pensamento de Wittgenstein - possa preencher esse lugar vazio na história do teatro, auxiliando-nos assim a pensar de outra forma aquilo que veio depois.

Osborne (2013: 19-20) segue a ideia da "arte contemporânea começando em algum momento no começo dos anos 1960", nascida de uma "ruptura ontológica com práticas baseadas em objetos e específicas aos meios", ruptura encarnada em "uma série 
KON, A. S. - Prólogo terminável e interminável

de novos tipos de trabalho, dos quais a performance, o minimalismo e a arte conceitual aparecem, retrospectivamente, como os mais decisivos"; essa ruptura não tem como marco nenhum evento "empírico, pontualmente datável”, mas "os próprios 'anos sessenta" entendidos como uma "conjunção complexa de radicalismos sociais, políticos e culturais" politicamente "epitomizados na figura de '1968', embora suas manifestações artísticas decisivas foram mais cedo na década". Ora, olhando para além das artes visuais (chamadas muitas vezes e de modo excludente apenas de "Arte"), as "peças de fala" aparecem como casos exemplares dessa ruptura, e seu projeto dramatúrgico como fundamentalmente conceitual. "Uma cadeira em cena é uma cadeira de teatro", insistia o escritor ao mesmo tempo que Kosuth criava "Uma e três cadeiras", apresentando lado a lado o objeto, sua imagem fotográfica e a imagem aumentada de sua definição no dicionário.

Se para esse artista conceitual "o 'valor' de determinados artistas depois de Duchamp pode ser medido de acordo com o quanto eles questionaram a natureza da arte" e "o que eles acrescentaram à concepção da arte" (KOSUTH 2006: 218, grifo do original), o trabalho de Handke na expansão da definição de teatro para além do drama atesta seu valor como artista conceitual. Se "trabalhos de arte [...] não fornecem nenhuma informação sobre algum fato", mas apenas "uma tautologia, [...] dizendo que um trabalho de arte em particular é arte" (219-20), há que lembrar de como a ênfase linguística do escritor austríaco visava justamente chamar a atenção para o fato de a representação artística dos fatos ser uma representação artística opaca, e não os fatos. Finalmente, se "a arte 'sobrevive' influenciando outra arte, e não como o resíduo físico das ideias de um artista” (219), talvez possamos explicar as limitações que muitos viram nas peças de Handke. Richard Gilman (1999: 283), por exemplo, as vê como "tentativas, golpes em um corpo resistente, sondas para criar aberturas em direção a uma renovação do teatro, e não acréscimos indestrutíveis e permanentes para o repertório teatral"; ele avalia ainda que "seu interesse se exaure rapidamente, uma vez que seu princípio procedural foi apreendido e uma vez que o espectador ou leitor tem seus olhos abertos para o que Handke está fazendo com a linguagem por um lado e com a ideia do teatro por outro". Seria inclusive "difícil imaginar querer assistir Acusando a si mesmo ou Afrontando o público mais de uma vez". Fritz Wefelmeyer (2005: 204) sublinha como a redação das peças decorre quase automaticamente de uma ideia inicial, um procedimento simplesmente aplicável, vendo “pouco mérito literário em criar essas sentenças, uma vez 
KON, A. S. - Prólogo terminável e interminável

que o falante sempre sabe de antemão o que vai ser dito”. Também cita críticas da época, que viam nas peças posteriores "basicamente nada de novo, só já familiar o truque de rotina de Afrontando o público". O próprio Handke, “quando questionado em 1975 sobre seus sentimentos a respeito de suas obras iniciais, [...] alegou que achava duas das peças, Predizendo o futuro e Chamando por socorro, lisas demais e excessivamente formalistas, e pensava que todo seu corpus ficaria melhor se elas pudessem ser removidas" (CALANDRA 1983: 54). ${ }^{13}$

"Desse ponto de vista", conclui e insiste Osborne (2013: 48), "a arte contemporânea é arte pós-conceitual", tendo como premissa "a experiência histórica complexa e o legado crítico da arte conceitual, amplamente concebida, que registra sua mutação fundamental da ontologia da obra de arte". Mas o prefixo "pós” indica que é "um erro supor que, porque é conceitual, não há nenhum papel nela para a 'estética", que pelo contrário se revela "um aspecto ineliminável”, por mais que os artistas conceituais o quisessem eliminar - e é por isso que não se trata de dizer que a arte contemporânea seja ainda simplesmente conceitual (45). É nesse mesmo sentido que o teatro contemporâneo é, além de pós-brechtiano, pós-handkeano; podemos assim adaptar para o dramaturgo austríaco a fórmula de Lehmann (2011: 34) sobre o alemão: um teatro que [...] tem consciência de que é marcado pelas reivindicações e questões sedimentadas na obra de Brecht [e na de Handke] mas não pode mais aceitar as respostas dadas por Brecht [e Handke]". Com isso queremos deixar claro que as "peças de fala" são, enquanto obras conceituais, de certo modo datadas, e que para elas vale o que Osborne chama o “'fracasso' da Arte Conceitual em seu programa forte, 'puro' ou analítico; ou seja, a ideia de uma arte 'puramente' conceitual” (OSBORNE 2013: 48-9). Só há fracasso, porém, como “demonstração prática da incoerência de uma autocompreensão particular" e não “fracasso artístico" (49, grifo do original). Essa concepção nos dá uma chave para decifrar um enigma recorrente nos estudos sobre o teatro de Peter Handke: o suposto caráter "conservador" de suas obras posteriores, que aos poucos começam a apresentar personagens, ações e representação ficcional, num aparente retrocesso em relação à experimentação do começo da carreira, e sobretudo das quatro peças de fala aqui discutidas. Contra essa avaliação precipitada, o próprio autor diz que "desde Afrontando

\footnotetext{
${ }^{13}$ Anos depois, porém, Handke reavalia as duas peças: sobre uma nova montagem musical de Predizendo o futuro, diz "Eu fiquei surpreso comigo mesmo, e foi bom, foi selvagem"; e, sobre Chamando por socorro, "aquilo não era tão estúpido, no fundo. Ninguém mais encena, mas é pelo menos interessante" (HANDKE e OBERENDER 2014: 166 e 76, respectivamente).
}

Pandaemonium, São Paulo, v. 24, n. 43, mai.-ago. 2021, p. 111-138 
KON, A. S. - Prólogo terminável e interminável

o público até agora há uma continuidade" (HANDKE e OBERENDER 2014: 164) e que ele gostaria "que alguém algum dia mostrasse - que o teatro como ação faz sempre parte do jogo, como possibilidade e como meio o teatro sempre faz parte do jogo", e isso "em todas as peças" $(70)^{14}$. Mas também há algo que muda em relação às peças de juventude: “agora eu o defendo, agora eu acredito no teatro" (104).

E é assim que o desejo de Peter Handke de que suas primeiras peças fossem um prólogo - intuito expresso tanto pelos oradores de Afrontando o público quanto pelo próprio autor em entrevistas - deve ser visto como realizado de modo muito mais amplo e fundamental do que ele poderia ter imaginado quando as escreveu. "O que importava para mim era fazer [os espectadores] terem vontade de ir mais ao teatro, fazê-los ver todas as peças mais conscientemente e com uma consciência diferente. Meu plano teatral é ter a plateia sempre olhar para minha peça como um meio de testar outras peças" (HANDKE e JOSEPH 1970: 58). O que a história do teatro mostrou é as peças de fala criaram um novo parâmetro não apenas para os espectadores, mas também para o próprio autor, para outros criadores e para o teatro como um todo.

\section{Referências bibliográficas}

AdoRnO, Theodor. Teoria Estética. Trad. Artur Morão. São Paulo: Martins Fontes, 1982.

Benjamin, Walter. Anotações de Svendborg, Verão de 1934. Trad. Luciano Gatti. Viso: Cadernos de estética aplicada, v. 4, n. 9, 20-30, 2010.

Benjamin, Walter. Passagens. Trad. Irene Aron e Cleonice Paes Barreto Mourão. Belo Horizonte, Editora UFMG; São Paulo, Imprensa Oficial do Estado de São Paulo, 2009.

CALANDRA, Denis. Modern German Dramatists. Londres: Macmillan, 1983.

DÜTTMAN, Alexander García; GRITZNER, Karoline. On Participation in Art: A conversation with Alexander García Düttman. Performance Research, v. 16, n. 4, 136-140, 2011.

EAGLETON, Terry. Materialism. New Haven: Yale University Press, 2016.

FISCHER-LICHTE, Erika. Ästhetik des Performativen. Frankfurt: Suhrkamp, 2004.

GILMAN, Richard. The making of modern drama: a study of Büchner, Ibsen, Strindberg, Chekhov, Pirandello, Beckett, Brecht, Handke. New Haven: Yale University Press, 1999.

HAMACHER, Werner. Aformativo, greve: a "crítica da violência" de Benjamin. In: BENJAMIN, Andrew; OsBorne, Peter (orgs.). A filosofia de Walter Benjamin. Rio de Janeiro: Zahar, 1997, 122-148.

HANDKE, Peter. Aufsätze I. Berlim: Suhrkamp, 2018.

\footnotetext{
${ }^{14}$ Handke admite uma exceção para esse caráter metateatral de suas peças: o texto Die Unvernünftigen sterben aus, único caso em que "o teatro como espaço não desempenha de fato nenhum papel" e "faz-se como se fosse a realidade, o mundo exterior" (ibid.). É claro que não há nenhuma possibilidade de aceitar automaticamente a avaliação do autor sobre suas próprias peças, que precisariam ser analisadas caso a caso para concluir se estão ou não à altura do desafio que o próprio escritor havia lançado em sua juventude.
}

Pandaemonium, São Paulo, v. 24, n. 43, mai.-ago. 2021, p. 111-138 
KON, A. S. - Prólogo terminável e interminável

HANDKE, Peter; JoSEPH, Artur. Nauseated by Language: From an Interview with Peter Handke. The Drama Review, v. 15, n. 1, 56-61, 1970.

HANDKE, Peter; OBERENDER, Thomas. Nebeneingang oder Haupteingang? Gespräche über 50 Jahre Schreiben fürs Theater. Berlim: Suhrkamp, 2014.

HERn, Nicholas. Peter Handke: Theatre and Anti-theatre. Londres: Oswald Wolff, 1971.

JAKOBSON, Roman. Linguística e comunicação. Trad. Izidoro Blikstein e José Paulo Paes. São Paulo: Cultrix, 1992.

JAMESON, Fredric. The prison-house of language: A critical account of Structuralism and Russian Formalism. Princeton: Princeton University Press, 1972.

Kosuth, Joseph. "A arte depois da filosofia". Trad. Pedro Süssekind. In: FerREIRA, Glória; COTRIM, Cecilia (org.). Escritos de artistas: anos 60/70. Rio de Janeiro: Jorge Zahar, 2006, 210-234.

LECERCLE, Jean-Jacques. A Marxist Philosophy of Language. Leiden: Brill, 2006.

LeHMann, Hans-Thies. Teatro pós-dramático. Trad. Pedro Süssekind. São Paulo: Cosac Naify, 2011.

MENKE, Christoph. "Práxis e Jogo: comentários acerca da dialética de um teatro pós-vanguarda". Trad. Stephan Baumgärtel. Urdimento, v.1, n. 14, 11-19, 2010.

MENKE, Christoph. La actualidade de la tragédia: Ensayo sobre juicio y representación. Trad. Remei Werning. Madri: A. Machado Libros, 2008

MÜLLER-SCHÖLL, Nikolaus. Beschimpfen, Ignorieren, Manipulieren. Zur Politik mit dem Publikum nach Peter Handke. In: HoCHHOLDINGER-REITERER, Beate; BoESCH, Géraldine; BEHN, Marcel (orgs.). Publikum im Gegenwartstheater. Berlin: Alexander, 2018, 73-92.

NÄGELE, Rainer. Peter Handke: Aspekte eines experimentellen Theaters. Colloquia Germanica, v. 14, n. 3, 220-228, 1981.

OSBORNe, Peter. Anywhere or not at all: Philosophy of contemporary art. Londres: Verso, 2013.

PERLOFF, Marjorie. Edge of Irony: Modernism in the Shadow of the Habsburg Empire. Chicago: The University of Chicago Press, 2016.

PERLOFF, Marjorie. The Conceptualist Turn: Wittgenstein and the New Writing. In: Andrea Andersson (ed.). Postscript: writing after conceptual art. Toronto: University of Toronto Press, 2018, 27-40.

RANCIÈRE, Jacques. Le spectateur emancipé. Paris: La Fabrique, 2008.

RANCIÈRE, Jacques; MORENO, Melina Balcázar. "A política é imaginação": Entrevista com Jacques Rancière. Trad. Centro de Promoção de Agentes de Transformação (CEPAT). In: Instituto Humanitas Unisinos, julho de 2018. http://www.ihu.unisinos.br/78noticias/581209-a-politica-e-imaginacao-entrevista-com-jacques-ranciere (09/04/2020).

RORTY, Richard (ed.). The linguistic turn: essays in philosophical method. Chicago: The University of Chicago Press, 1992.

SARTRE, Jean-Paul. Que é a literatura? Trad. Carlos Felipe Moisés. São Paulo: Ática, 2004.

SHAPIRO, Michael J. Toward a Politicized Subject: Peter Handke and Language. boundary 2, v. 13, n. 2/3, 393-418, 1985.

Signeu, Samir (org. e trad.). Peter Handke: Peças faladas. São Paulo: Perspectiva, 2015.

VANDERATH, Johannes. Peter Handkes Publikumsbeschimpfung: Ende des aristotelischen Theaters? In: The German Quarterly 43(2), 1970, 317-326.

WEFELMEYER, Fritz. Handke's Theater. In: COURY, David N.; PILIPP, Frank (eds.). The Works of Peter Handke International Perspectives. Riverside: Ariadne Press, 2005, 194-235. 